\title{
PERSEPSI SISWA TERHADAP KOMPETENSI KEPRIBADIAN GURU DI SEKOLAH MENENGAH KEJURUAN (SMK) NEGERI 1 SOLOK
}

\author{
Dilweni Permata Wahyu ${ }^{1}$, Ahmad Sabandi ${ }^{2}$, Nelfia Adi ${ }^{3}$, Lusi Susanti ${ }^{4}$. \\ 1,2,3,4 Administrasi Pendidikan, Universitas Negeri Padang \\ Dilweni Permata Wahyu ${ }^{1}$, e-mail: dilwenipermatawahyu98@gmail.com \\ Ahmad Sabandi ${ }^{2}$, e-mail: sabandi@fip.unp.ac.id \\ Nelfia Adi ${ }^{3}$, e-mail: nelfiaadi@ fip.unp.ac.id \\ Lusi Susanti ${ }^{4}$, e-mail: lusy_mp@yahoo.com
}

\begin{abstract}
The purpose of this study was made to see and get information about how capable students' perceptions of teacher personality competence are in carrying out their duties. There are five questions to be answered in this study, namely 1) How do students 'perceptions of the personality of the noble character possessed by the teacher in carrying out their duties at Vocational High School (SMK) Negeri 1 Solok, 2) How do students' perceptions of a personality that is steady and stable teachers have in carrying out their duties in Vocational High School (SMK) Negeri 1 Solok, 3) How do students' perceptions of the adult personality possessed by the teacher in carrying out their duties at Vocational High School (SMK) Negeri 1 Solok, 4) What is the student's perspective about the wise and wise personality possessed by teachers in carrying out their duties at Vocational High School (SMK) Negeri 1 Solok, 5) How do students' perceptions of the authoritative personality possessed by teachers in carrying out their duties at Vocational High School (SMK) Negeri 1 Solok. This type of research is quantitative descriptive with the population in this study are all students of class XI and XII at SMK Negeri 1 Solok with 955 students and a sample of 91 people. Sampling was determined using the Slovin formula and taken using simple random sampling technique. The research instrument used was a questionnaire with a Likert scale model, amounting to 30 statements. The data collected is then processed and the average score (mean) and the respondent's level of achievement (TCR) are sought. The results of data processing show that the teacher's personality competence seen from the indicators of noble character gets an average score of 3.83 with a respondent's achievement level (TCR) of $76.6 \%$, a steady and stable personality gets an average score of 3.65 , the respondent's level of achievement ( TCR) 73\%, adult personalities get an average score of 3.59 with the respondent's achievement level (TCR) $71.8 \%$, wise and wise personalities get an average score of 3.53 with a respondent's achievement level (TCR) of 70,6\%, and an authoritative personality got an average score of 3.63 with the respondent's achievement level (TCR) of 72.6\%. Overall students' perceptions of teacher personality competence in Vocational High School (SMK) Negeri 1 Solok obtained an average score of 3.64 with a respondent's achievement level (TCR) of $72.8 \%$.
\end{abstract}

\begin{abstract}
Abstrak
Tujuan penelitian ini dibuat untuk melihat dan memperoleh informasi mengenai persepsi siswa terhadap kompetensi kepribadian guru dalam menjalankan tugasnya. Ada lima pertanyaan yang mau dijawab saat penelitian ini, yaitu 1) Bagaimanakah persepsi siswa terhadap kepribadian berakhlak mulia yang dimiliki oleh guru dalam menjalankan tugasnya di Sekolah Menengah Kejuruan (SMK) Negeri 1 Solok, 2) Bagaimanakah persepsi siswa terhadap kepribadian yang mantap dan stabil yang dimiliki oleh guru dalam melakukan tugasnya di Sekolah Menengah Kejuruan (SMK) Negeri 1 Solok, 3) Bagaimanakah persepsi siswa terhadap kepribadian yang dewasa yang dimiliki oleh guru dalam melakukan tugasnya di Sekolah Menengah Kejuruan (SMK) Negeri 1 Solok, 4) Bagaimanakah persepsi siswa terhadap kepribadian yang arif dan bijaksana yang dimiliki oleh guru dalam melaksanakan tugasnya di Sekolah Menengah Kejuruan (SMK) Negeri 1 Solok, 5) Bagaimanakah persepsi siswa terhadap kepribadian yang berwibawa dimiliki oleh guru dalam menjalankan tugasnya di Sekolah Menengah Kejuruan (SMK) Negeri 1 Solok. Jenis penelitian yang dilakukan adalah deskriptif kuantitatif dengan populasi pada penelitian ini adalah semua siswa kelas XI dan XII di SMK Negeri 1 Solok dengan siswa yang berjumlah 955 orang dan sampel sebanyak 91 orang. Penarikan sampel ditentukan dengan memakai rumus slovin dan dilaksanakan dengan memakai teknik simple random sampling. Instrumen penelitian yang dipakai adalah angket dengan model Skala Likert yang berjumlah 30 butir pernyataan. Data yang dikumpulkan lalu diolah dan dicari skor ratarata (Mean) serta tingkat capaian responden (TCR). Hasil pengolahan data menunjukkan bahwa kompetensi kepribadian guru dilihat dari indikator berakhlak mulia mendapat skor rata-rata 3,83 serta tingkat capaian responden (TCR) 76,6\%, kepribadian yang mantap dan stabil mendapat skor rata-rata
\end{abstract}


3,65 serta tingkat capaian responden (TCR) 73\%, kepribadian yang dewasa mendapat skor rata-rata 3,59 serta tingkat capaian responden (TCR) $71,8 \%$, kepribadian yang arif dan bijaksana mendapat skor ratarata 3,53 serta tingkat capaian responden (TCR) 70,6\%, dan kepribadian yang berwibawa mendapat skor rata-rata 3,63 serta tingkat capaian responden (TCR) 72,6\%. Keseluruhan persepsi siswa terhadap kompetensi kepribadian guru di Sekolah Menengah Kejuruan (SMK) Negeri 1 Solok memperoleh skor rata-rata 3,64 serta tingkat capaian responden (TCR) 72,8\%.

Kata Kunci: Persepsi siswa, Kompetensi Kepribadian Guru

How to Cite: Dilweni Permata Wahyu ${ }^{1}$, Ahmad Sabandi ${ }^{2}$, Nelfia Adi ${ }^{3}$, Lusi Susanti ${ }^{4}$. 2021. Persepsi Siswa Terhadap Kompetensi Kepribadian Guru di SMK Negeri 1 Solok. Journal Educational Administration and Leadership, Vol (N): pp. XX-XX, DOI: 10.24036/XXXXXXXXXX-X-XX

This is an open access article distributed under the Creative Commons 4.0 Attribution License, which permits unrestricted use, distribution, and reproduction in any medium, provided the original work is properly cited. (C2020 by author.

\section{Pendahuluan}

Pendidikan yakni gambaran untuk masa depan yang terpenting oleh umat manusia. Untuk menjadikan pendidikan yang berkualitas perlu adanya guru yang berkualitas pula, karena guru merupakan orang terdepan yang akan berinteraksi langsung dengan siswa. Guru adalah salah satu unsur yang paling penting pada pendidikan. Menurut Sagala (2011:6) Guru memiliki tugas merencanakan dan melakukan proses belajar mengajar, meneliti hasil proses pembelajaran, melaksanakan pengarahan dan pelatihan, melaksanakan riset dan pengkajian, dan melakukan hubungan dengan komunitas.

Tugas menjadi seorang guru, didukung dengan beberapa kompetensi yang mendukungnya, kompetensi itu berlandaskan Undang-Undang yang berlaku di Indonesia adalah kompetensi kepribadian, kompetensi pedagogik, kompetensi profesional, dan kompetensi sosial (Undang-Undang RI No. 14 Tahun 2005). Guru yaitu guru profesional yang memiliki tugas untuk membabarkan kepribadian siswa atau saat ini populer disebut dengan istilah karakter siswa. Pendidik yang memahami kompetensi kepribadian justru banyak menolong cara dalam peningkatan karakter siswa. Tanpa adanya maksud mengabaikan kompetensi yang lainnya, yang layak dikuasai seorang guru, kompetensi kepribadian barangkali patut memperoleh ketertarikan yang banyak, karena guru patut memperoleh kepribadian yang menggambarkan seorang pendidik. Guru dijadikan seperti panutan oleh peserta didiknya dan masyarakat. Ujian yang sulit untuk pendidik dalam urusan kepribadian ini ialah stimulasi yang menghasut emosinya. Kesetimbangan emosi harus diperlukan . Peserta didik merasa takut apabila guru tersebut mudah marah, dan ketakutan itu mengakibatkan rendahnya konsentrasi belajar siswa serta kurangnya minat siswa untuk mengikuti pembelajaran, sebab ketakutan menimbulkan kekhawatiran untuk dimarahi. Sudah merupakan tanggung jawab guru untuk menyerahkan beberapa norma kepada siswa agar mengetahui mana tingkah laku bermoral dan amoral, mana tingkah laku yang susila dan asusila. Contohnya melalui perbuatan, sikap dan tingkah laku. Pendidikan dilaksanakan tidak hanya dengan perkataan, tetapi melalui perbuatan, sikap dan tingkah laku.

Dengan mengedepankan selaku pribadi yang bisa diikuti ajarannya dan dapat dicontoh, secara psikologi siswa menjurus menganggap teguh pada segala sesuatu yang patut diajarkan gurunya. Sebagai contoh, saat guru mengarahkan terkait sopan santun terhadap siswanya, akan tetapi disisi lain secara sadar atau tidak sadar, gurunya itu justru sering mudah marah dan berlaku kasar, oleh karena itu yang hendak melekat pada peserta didiknya bukanlah perilaku sopan santun, akan tetapi perilaku kasar itulah yang banyak tertanam dalam otak dan keyakinan peserta didiknya. Sehingga tantang menjadi seorang guru adalah menjadi ujung tombak dari sebuah pendidikan. Apakah melalui pribadi yang diperoleh oleh guru dapat membawa siswanya ke sis kesuksesan meraih tujuan, atau malah sebagai perusak masa depan siswanya.

Kenyataan yang notulis temukan di lapangan ketika melaksanakan observasi selama enam bulan pada sekolah tempat peneliti melakukan penelitian, terdapat indikasi permasalahan pada kompetensi kepribadian guru diantaranya yang pertama masih adanya guru yang kurang memiliki sikap saling tolong menolong. Ini terlihat bahwa saat dalam proses pembelajaran ada guru yang tidak mau menggantikan guru yang berhalangan hadir untuk datang ke sekolah. Kedua masih adanya guru yang memberikan teladan yang kurang baik kepada siswanya. Ini terlihat dari adanya guru yang seharusnya mengajar tiga jam (3x45 menit) pelajaran tetapi guru tersebut hanya masuk ke dalam kelas pada satu jam terakhir (1x45 menit). Ketiga masih adanya guru yang memiliki motivasi mengajar rendah. Hal ini tampak saat dalam proses pembelajaran guru kurang peduli terhadap siswa yang malas untuk belajar. Keempat masih adanya guru yang memiliki sifat yang kurang stabil seperti emosi kepada siswanya. Ini terlihat ketika siswa yang sedang bermasalah dengan salah seorang guru, lalu siswa tersebut memberikan tugasnya. Ketika siswa tersebut memberikan tugasnya, guru langsung merespon dengan sikap yang kurang baik (melempar buku siswa tersebut). Kelima masih adanya guru yang 
kurang wibawa terhadap sesama rekan kerja dan siswanya, hal ini terlihat saat rapat guru masih ada yang adu pendapat dan belum menghargai hasil pendapat rekan kerjanya serta masih adanya guru yang kurang saling menghormati siswanya hal ini dilihat dari guru saat menegur dengan sikap marah secara langsung.

\section{Metode Penelitian}

Penulisan artikel ini berdasarkan pada penelitian dengan pendekatan deskriptif. Pendekatan deskriptif yaitu penelitian yang berusaha menjawab fenomena yang terjadi di lapangan dengan memaparkan fakta-fakta di lapangan (Sudaryono, 2018:82).Populasi terhadap penelitian ini merupakan siswa kelas XI dan XII pada Sekolah Menengah Kejuruan Negeri 1 Solok sebanyak 955 orang. Terdiri dari jurusan akuntansi sebanyak 279 orang, perkantoran sebanyak 273 orang, pemasaran sebanyak 150 orang, teknik komputer jaringan sebanyak 125 orang, broadcast sebanyak 83 orang, dan perfilman sebanyak 45 orang.

Dari keseluruhan populasi tersebut ditarik sampel, dalam memutuskan jumlah sampel penelitian ini, maka penulis memakai rumus Slovin (Widodo, 2018:71) dengan perkiraan tingkat kesalahan 10\%. Berdasarkan hal tersebut didapatkan jumlah sampel sebanyak 91 orang. Jenis data selama penelitian ini yakni data kuantitatif, atau data yang berwujud angka-angka yang menggambarkan keadaan objek yang diteliti. Data yang diperoleh dalam penelitian bersumber dari siswa kelas XI dan XII dengan mempertimbangkan penarikan sampel yang dilakukan.

Alat pengumpul data yang peneliti gunakan adalah memakai Angket dengan skala Likert. Sebelum digunakan untuk mengumpulkan data, dilakukan uji validitas dan reliabilitas terhadap angket yang akan digunakan. Hasil dari uji validitas yang diujikan pada 20 orang responden di luar sampel yang ditentukan, diperoleh 3 item pernyataan yang tidak valid dari total 33 item pernyataan, sehingga pada penelitian hanya digunakan 30 item pernyataan saja. Hasil uji reliabilitas angket menunjukan bahwasanya angket penelitian yang digunakan, Reliabel dengan $\mathrm{R}$ hitung sebesar 0,933 dan $\mathrm{R}$ tabel sebesar 0,444 menggunakan taraf kepercayaan 5\%. Pengolahan data hasil penelitian dilakukan dengan menggunakan rumus Mean dan menggunakan rumus Tingkat Capaian Responden (TCR)

\section{Hasil dan Pembahasan}

a. Hasil Penelitian

Hasil akhir penelitian di Sekolah Menengah Kejuruan (SMK) Negeri 1 Solok. Hasil Penelitian mengenai persepsi siswa tentang berakhlak mulia guru ketika menjalankan tugasnya di Sekolah Menengah Kejuruan (SMK) Negeri 1 Solok dengan memperoleh skor rata-rata 3,83 dan TCR 76,6 dengan kriteria cukup baik. Persepsi siswa tentang kepribadian yang mantap dan stabil guru di Sekolah Menengah Kejuruan (SMK) Negeri 1 Solok dengan memperoleh skor rata-rata 3,65 dan TCR 73 dengan kriteria cukup baik. Persepsi siswa tentang kepribadian yang dewasa guru di Sekolah Menengah Kejuruan (SMK) Negeri 1 Solok dengan memperoleh skor rata-rata 3,59 dan TCR 71,8 dengan kriteria cukup baik. Persepsi siswa tentang kepribadian kepribadian yang arif dan bijaksana pendidik di Sekolah Menengah Kejuruan (SMK) Negeri 1 Solok dengan memperoleh skor rata-rata 3,53 dan TCR 70,6 dengan kriteria cukup baik. Persepsi siswa tentang kepribadian yang berwibawa guru di Sekolah Menengah Kejuruan (SMK) Negeri 1 Solok dengan memperoleh skor rata-rata 3,63 dan TCR 72,6 dengan kriteria cukup baik. Secara keseluruhan hasil penelitian tentang persepsi siswa terhadap kompetensi kepribadian guru di Sekolah Menengah Kejuruan (SMK) Negeri 1 Solok dinyatakan cukup baik. Rinciannya adalah sebagai berikut: indikator berakhlak mulia dengan rata-rata 3,83, kepribadian yang mantap dan stabil dengan rata-rata 3,65, kepribadian yang dewasa pada rata-rata 3,59, kepribadian yang arif dan bijaksana dengan rata-rata 3,53, dan kepribadian yang berwibawa pada rata-rata 3,65 .

b. Pembahasan

Untuk lebih pembahasan hasil penelitian perihal persepsi siswa terhadap kompetensi kepribadian guru di SMKN 1 Solok dilihat dari indikator berakhlak mulia, kepribadian yang mantap dan stabil, kepribadian yang dewasa, kepribadian yang arif dan bijaksana dan kepribadian yang berwibawa.

\section{Persepsi Siswa Tentang Kompetensi Kepribadian Guru Dilihat dari Indikator Berakhlak Mulia}

Persepsi siswa terhadap kompetensi kepribadian guru yang ditinjau dari guru berakhlak mulia, berdasarkan hasil penelitian yaitu cukup baik dengan meraih skor rata-rata 3,83 dengan TCR 76,6\%. Indikator berakhlak mulia tersebut diperoleh item yang mempunyai skor paling rendah yakni pada item tolong menolong oleh guru tersebut. Tolong menolong terhadap sesama guru yaitu memperoleh skor ratarata 3,68 dan TCR 73,63\% pada kriteria cukup baik

Salah satu penyebab rendahnya rata-rata tingkat capaian pada item guru mampu menerapkan sikap saling tolong menolong sesama guru tersebut adalah kurangnya rasa kepedulian sosial sesama guru. Hal ini seiring dengan yang disampaikan oleh Nisa (2017:35) peduli adalah memedulikan atau memandang 
sesuatu, peduli sosial yang dimaksud tidak untuk ikut campur dengan kegiatan orang lain, namun lebih terhadap menolong mengatasi persoalan yang dihadapi oleh orang lain dengan maksud baik juga damai. Pentingnya sikap peduli sosial antara guru di sekolah banyak dibutuhkan contohnya sebagai bentuk toleransi antara sesama guru, saling memahami permasalahan satu sama lain, dan bentuk pengertian atas kesulitan yang sedang dialami oleh seseorang. Terjadinya berbagai bentuk hubungan antara guru dengan guru dapat mengembangkan sikap peduli sosial yang tertancap di dalam diri masing-masing individu anggota masyarakat. Selain itu peran kepala sekolah dalam menjaga komunikasi dan hubungan antar sesama guru juga sangat diperlukan. Selain memperhatikan keadaan guru di sekolah tersebut kepala sekolah juga hendaknya mengadakan suatu pertemuan atau kegiatan yang dapat menumbuhkan rasa peduli dan saling toleransi di antara guru seperti darmawisata atau pertemuan bulanan

\section{Persepsi Siswa Tentang Kompetensi Kepribadian Guru Dilihat dari Indikator Kepribadian yang Mantap dan Stabil}

Kepribadian yang mantap dari seorang pendidik hendak menyerahkan cerminan yang bagus kepada siswa maupun dalam lingkungan masyarakat, maka guru hendak muncul sebagai pribadi yang patut menjadi panutan untuk ditiru sikap dan perilakunya juga menaati nasehat dan ucapannya. Persepsi siswa terhadap kompetensi kepribadian guru SMKN 1 Solok dipantau dari kepribadian yang mantap dan stabil dari guru di sekolah tersebut mendapatkan rata-rata 3,65 dengan TCR 73\%, dengan hasil demikian, berada pada kategori cukup baik. Pada indikator pribadi yang mantap dan stabil ini terdapat item yang memiliki rat-rata yang rendah yakni guru mampu bersikap baik kepada peserta didik, dengan rata-rata 3,47 dan TCR 74,73\%.

Salah satu penyebab rendahnya skor rata-rata pada pernyataan guru mampu bersikap baik kepada siswa menyimpang dari keadaan yang sebenarnya dikarenakan adanya paradigma guru yang menganggap siswa yang menyimpang pasti memiliki sikap yang kurang baik. Sebenarnya seorang guru tidak boleh memiliki paradigma yang seperti itu, karena di antara lain kompetensi yang wajib dipunyai oleh pendidik ialah kompetensi kepribadian.

Pada kenyataannya semua siswa mempunyai kesulitan dalam prestasi belajar maupun dalam perbuatannya. Dalam hal ini siswa mendapati kasus tak bermakna siswa itu mesti dihindari ataupun di marahi atas perbuatannya yang menyimpang. Di sekolah guru condong pilih kasih terhadap anak yang mempunyai potensi intelektual tinggi dan mempunyai sikap dan perbuatan yang baik, namun siswa yang bandel cenderung dibenci sehingga siswa itu bisa makin bandel akibat perbuatan yang dibiarkan. Perbuatan pendidik yang semacam ini harusnya tak dikembangkan sebaliknya harus dimusnahkan supaya dalam proses belajar mengajar teraih harapan tersebut.

Pendidik selaku pembina berupaya untuk dapat menciptakan beraneka ragam kemampuan yang dimilikinya, membina peserta didik supaya dapat memperoleh dan menjalankan tugas perkembangan peserta didik tersebut sehingga dengan teraihnya itu siswa mampu tumbuh dan berkembang seperti pribadi yang mandiri dan produktif. Guru yang berupaya melakukan perannya dengan baik, membuat individu siswanya sangat diperlukan dalam pelaksanaan proses belajar mengajar. Dalam kenyataannya setiap pendidik belum bisa melakukan perannya dengan baik. Pada proses pembelajaran seharusnya seorang guru tidak hanya memberikan materi-materi pembelajaran saja, tetapi harus ada penanaman kepribadian pada pribadi siswa

\section{Persepsi Siswa Tentang Kompetensi Kepribadian Guru Dilihat dari Indikator Kepribadian yang Dewasa}

Kedewasaan yang dimaksudkan adalah kedewasaan dalam berpikir, bertindak, dan memiliki pendirian/komitmen. Persepsi siswa pada SMKN 1 Solok terhadap kompetensi kepribadian guru dilihat dari kepribadian yang dewasa seorang guru, berdasarkan penelitian mendapatkan skor rata-rata 3,59 dengan TCR sebesar 71,8\%, berada pada kategori cukup baik. Pada indikator kepribadian yang dewasa, item yang mendapatkan nilai rata-rata terendah adalah guru mampu membantu siswa dalam menyelesaikan masalah yang dihadapinya dengan nilai rata-rata 3,49 dengan TCR sebesar 69,89\% berada pada kategori cukup baik.

Salah satu penyebab rendahnya item tersebut dikarenakan guru tidak memahami secara jelas apa yang menjadi persoalan pada seorang peserta didik. Oleh karena itu seorang guru harus dapat berempati pada peserta didiknya. Pada dasarnya seorang guru harus memiliki dan mengembangkan salah satu sikap kepribadiannya yaitu sikap empati terhadap siswa. Dimana empati dalam bahasa indonesia diterjemahkan sebagai sambung rasa yaitu keahlian individu buat mengetahui kata hati dan pikiran orang lain yang belum memiliki arti emosional untuk pribadinya sendiri. Intinya menurut Daymond, (1949:145-152) membagi empati menjadi dua kategori utama yaitu sebagai suatu keterampilan menggambarkan peran diri orang lain dan memahami juga tempat memperkirakan apa yang dipikirkan, dirasakan dan dilaksanakan oleh orang tersebut dan sebagai reaksi emosi seseorang yang berlainan satu dengan yang lain terkait pada kepandaian akan memperoleh emosi orang lain. 
Selain itu guru juga harus memiliki sikap simpati sehingga guru lebih dikagumi baik oleh sesama guru maupun siswa. Seorang guru seharusnya mempunyai sikap simpati supaya peserta didik merasa tertarik, baik dengan penampakan fisiknya maupun dengan caranya mengajar. Simpati menurut Nurfuadi (2020:172) simpati adalah suatu hasrat untuk turut merasakan apa yang dirasakan individu lain, dalam masyarakat simpati diartikan sebagai rasa senang atau tertarik kepada seseorang

\section{Persepsi Siswa Tentang Kompetensi Kepribadian Guru Dilihat dari Indikator Kepribadian yang Arif dan Bijaksana}

Kepribadian yang arif dan bijaksana yang dimaksud yaitu guru nan mengetahui dengan bagus ilmunya dan memanfaatkan pikirannya dalam bermacam keadaan, serta bisa mengelola diri dan emosinya dengan bagus. Persepsi siswa pada SMKN 1 Solok terhadap kompetensi kepribadian guru dilihat dari kepribadian yang arif dan bijaksana, berdasarkan penelitian memiliki nilai rata-rata 3,63 dengan TCR sebesar 72,6\% dengan kategori cukup baik. Nilai terendah pada indikator ini adalah terletak pada guru mampu berpartisipasi dalam kegiatan yang diadakan di sekolah, dan guru mampu menghasilkan ide atau ciptaan yang kreatif dan inovatif dengan meraih skor rata-rata sebesar 3,45 dan TCR sejumlah 69,01\% dengan kategori cukup baik.

Salah satu penyebab rendahnya guru mampu berpartisipasi dalam kegiatan yang diadakan di sekolah dan guru mampu mewujudkan ciptaan atau ide yang kreatif dan inovatif dikarenakan kurangnya rasa tanggung jawab guru terhadap kegiatan yang diadakan di sekolah tersebut. Sehingga guru kurang memberikan partisipasinya terhadap kegiatan tersebut. Seharusnya seorang pendidik tidak hanya berperan pada kegiatan belajar mengajar di kelas saja, akan tetapi guru pun harus ikut andil dalam kegiatan yang diadakan di sekolah. Sebagaimana salah satu kompetensi kepribadian yang patut diperoleh seorang pendidik menurut Satori (2007) guru selalu berdekatan dengan kelompok yang berlainan dan bermacam keunikan baik dari anak didik maupun dengan orang lain. Pada dasarnya kegiatan yang dilakukan oleh sekolah selalu berhubungan dengan komunitas atau orang lain, selain itu dengan mengikuti kegiatan yang diadakan oleh sekolah juga akan mengembangkan sifat kreatif guru yang mampu menjadi panutan bagi siswa di sekolah. Sesuai dengan pendapat Nurfuadi (2020:172) kreatif adalah kemampuan seorang guru untuk menemukan dan menciptakan hal-hal baru

\section{Persepsi Siswa Tentang Kompetensi Kepribadian Guru Dilihat dari Indikator Kepribadian yang Berwibawa}

Wibawa seorang guru dalam mengarahkan anak didiknya saat kegiatan proses belajar mengajar yaitu pembawaannya yang mampu memahami dan mengendalikan individu lain untuk menghargai melalui tingkah lakunya yang memuat kepemimpinan dan penuh daya tarik. Persepsi siswa pada SMKN 1 Solok terhadap kompetensi kepribadian guru dilihat dari kepribadian yang berwibawa, berdasarkan penelitian mendapatkan nilai rata-rata 3,63 dengan TCR sebesar 72,6\% berada pada kategori cukup baik. Nilai terendah pada indikator ini adalah guru mampu menunjukkan sikap peduli terhadap siswa dengan skor ratarata 3,52 dengan TCR 70,33\% dalam kategori cukup baik

Salah satu penyebab rendahnya skor rata-rata pada pernyataan guru mampu menunjukkan sikap peduli terhadap siswa dikarenakan guru kurang memiliki sikap simpati dan empati. Simpati berasal dari bahasa inggris sympathy yang berarti suatu hasrat untuk turut merasakan apa yang sedang dirasakan orang lain, dapat juga diartikan sebagai rasa senang atau tertarik kepada seseorang. Sedangkan empati menurut McDonald \& Messinger (2014) mendefinisikan empati adalah keahlian guna merasakan atau menggambarkan pengetahuan emosi individu lain. Menurut Cotton empati tak semata-mata sekedar keahlian afektif akan berbagi kata hati dan keahlian kognitif untuk mengetahui perihal individu lain, namun pribadi orang lain mempunyai keahlian berkomunikasi secara verbal dan nonverbal tatkala mengatakan empati tersebut. Dengan adanya sikap simpati dan empati tersebut akan menumbuhkan sikap peduli guru terhadap siswa

\section{Kesimpulan}

Berakhlak mulia dalam Kompetensi Kepribadian Guru di Sekolah Menengah Kejuruan (SMK) Negeri 1 Solok menurut persepsi siswa berada pada kategori cukup baik dengan memperoleh tingkat capaian responden $76,6 \%$. Dapat dilihat pada item tertinggi yaitu guru mampu menjalankan ibadah dengan baik sesuai dengan ajaran agama yang dianut dan item yang paling rendah adalah guru mampu menerapkan sikap saling tolong menolong terhadap sesama guru.

Kepribadian yang mantap dan stabil dalam Kompetensi Kepribadian Guru di Sekolah Menengah Kejuruan (SMK) Negeri 1 Solok menurut persepsi siswa berada pada kategori cukup baik dengan memperoleh tingkat capaian responden 73\%. Dapat dilihat pada item tertinggi yaitu guru mampu bersikap baik kepada kepala sekolah dan item yang paling rendah adalah guru mampu bersikap baik kepada siswa. 
Kepribadian yang dewasa dalam Kompetensi Kepribadian Guru di Sekolah Menengah Kejuruan (SMK) Negeri 1 Solok menurut persepsi siswa berada pada kategori cukup baik dengan memperoleh tingkat capaian responden $71,8 \%$. Dapat dilihat pada item tertinggi yaitu guru mampu bertanggung jawab terhadap tugas yang dilaksanakannya dan item yang paling rendah adalah guru mampu membantu siswa dalam menyelesaikan masalah yang dihadapinya.

Kepribadian yang arif dan bijaksana dalam Kompetensi Kepribadian Guru di Sekolah Menengah Kejuruan (SMK) Negeri 1 Solok menurut persepsi siswa berada pada kategori cukup baik dengan memperoleh tingkat capaian responden $70,60 \%$. Dapat dilihat pada item tertinggi yaitu guru mampu menjelaskan materi pembelajaran sesuai dengan silabus yang digunakan dan item yang paling rendah adalah guru mampu berpartisipasi dalam kegiatan yang diadakan di sekolah dan guru mampu menghasilkan ide atau ciptaan yang kreatif dan inovatif.

Kepribadian yang berwibawa dalam Kompetensi Kepribadian Guru di Sekolah Menengah Kejuruan (SMK) Negeri 1 Solok menurut persepsi siswa berada pada kategori cukup baik dengan memperoleh tingkat capaian responden $72,6 \%$. Dapat dilihat pada item tertinggi yaitu Guru mampu berpakaian yang sopan dan rapi dan item yang paling rendah adalah guru mampu menunjukkan sikap peduli terhadap siswa

\section{Daftar Rujukan}

Nurfuadi, Moh. Roqib \&. 2020. Upaya Mengembangkan Kepribadian Guru Yang Sehat Di Masa Depan. Yogyakarta: Cinta Buku.

Sagala, Syaiful. 2011. Konsep Dan Makna Pembelajaran. Bandung: Alfabeta.

Satori, Djam'an. 2007. Profesi Keguruan. Jakarta: Universitas Terbuka.

Sudaryono. 2018. Metodologi Penelitian. edited by R. Pers. Depok.

Undang-Undang RI No. 14 Tahun 2005 